\title{
Ketamin/ksilazin anestezi hemoreolojik bakış açısından güvenlidir: bir ilk rapor "hakkında (1)
}

\author{
Erkan Tomatır
}

Sayın Editör,

Akbudak ve ark.'nın “Ketamin/ksilazin anestezi hemoreolojik bakış açısından güvenlidir: bir ilk rapor" başılılı araştırma makalesini ilgiyle okudum [1]. Makalenin giriş bölümünde "ketamin/ksilazin anestezisinin hemoreolojik parametreler üzerine etkilerinin bilinmediği", tartışma bölümünde ise "bu çalışma ile ilk kez gösterildiği" ifadeleri kullanılarak, belirgin bir biçimde çalışmanın özgün olduğu vurgulanmıştır.

Ancak bu nitelemenin doğru olarak kabul edilmesine olanak yoktur. Şöyle ki;

1. Makalenin başlığında yer alan "hemoreoloji" terimi nispeten yeni olup, "klinik hemoreoloji” terimi ilk kez 1979'da önerilmiş ve Avrupa Klinik Hemoreoloji ve Mikrosirkülasyon Derneği de 1990'da kurulmuştur [2]. Terimin konusu ise çok eski olup, tıp tarihi ile paralellik göstermektedir [3].

2. Sözlük anlamı "kan damarlarındaki basınç, akım, hacim ve dirençler, özellikle de mikrodolaşımdaki kırmızı kan hücreleri deformasyonu ve kan viskozitesi ile ilişki temelinde "kan akımını inceleyen bilim" olarak tanımlanmaktadır [4]. Terimin oldukça genel nitelikte olduğu ve geniş bir kapsama alanı içerdiği açıktır.

3. Hemoreolojinin ana unsuru olarak kabul edilen "viskozite" kelimesi ile tarama yapıldığında; ketaminin viskozite üzerine etkisi konusundaki ilk yayının 1974 yılında, yani henüz "klinik hemoreoloji" terimi ortada yokken yapıldığı görülmektedir [5]. Ayrıca ketaminin mikrodolaşıma [6], kan damarlarına [7] ve trombosit agregasyonuna etkileri [8] yanısıra ksilazin'in de viskozite [9] ve trombosit agregasyonu üzerine etkileri [10] üzerine çok sayıda yayına rastlanmıştır.
4. Yukarıda değinilen yayınlara makalenin tartışma bölümünde de değinilmemiş olması dikkat çekicidir. Makalenin mevcut haliyle, okurların ketamin ve ksilazin gibi iki eski ilacın kan akımına etkileri ve bu bağlamdaki güvenilirlikleri konusunda daha önce hiçbir bilgi bulunmadığını sanmaları kaçınılmazdır. Oysa; bunun doğru olmadığını, konuya ilişkin epeyce çalışma ve bilgi olduğunu kabul etmek gerekir.

Sonuç olarak; bir çalışmanın özgünlük değerini saptamaya yönelik güvenilir bir literatür taraması yapabilmek için anahtar kelimelerin doğru belirlenmesi kritik önem taşımaktadır. Hedef yayınları atlamamak için tek bir terim ile yetinilmemesi, konu ile yakın ilgili ya da benzer anlamda kullanılabilen alternatif kelimelerin de özenle taramaya dahil edilmesi gerekir.

\section{Kaynaklar}

1. Akbudak İH, Kilic Erkek O, Tuzcu EB, Pakyurek H, Bor Kucukatay M. Ketamine/xylazine anesthesia is safe in hemorheological point of view: a preliminary report. Pam Med J 2021;14:444-450. https://dx.doi. org/10.31362/patd.839939

2. Stoltz JF. History and future of hemorheology: from Rejkjavik to Lisboa. Clin Hemorheol Microcirc 2016;64:525-539. https://doi.org/10.3233/CH-168035

3. Rampling MW. The history of the theory of the circulation of the blood. Clin Hemorheol Microcirc 2016;64:541-549. https://doi.org/10.3233/CH-168031

4. Hemorheology. Available at: https://medical-dictionary. thefreedictionary.com/hemorheology. Accessed April 02, 2021

5. Magora F, London M, Eimerl D, Aronson HB. Blood viscosity during anaesthesia with halothane, cyclopropane, thiopentone and ketamine. Br J Anaesth 1974;46:343-347. https://doi.org/10.1093/bja/46.5.343

6. Lehmann Ch, Feyerherd F, Feyerherd T. Ketamine does not affect intestinal microcirculation in pentobarbital-anaesthetized rats during experimental endotoxaemia. Lab Anim 2007;4:55-62. https://doi. org/10.1258/002367707779399491 
7. Kanmura Y, Missiaen L, Casteels R. The effects of ketamine on $\mathrm{Ca} 2+$ movements in $\mathrm{A} 7 \mathrm{r} 5$ vascular smooth muscle cells. Anesth Analg 1996;83:1105-1109. https:// doi.org/10.1097/00000539-199611000-00036

8. Nakagawa $T$, Hirakata $H$, Sato $M$, et al. Ketamine suppresses platelet aggregation possibly by suppressed inositol triphosphate formation and subsequent suppression of cytosolic calcium increase. Anesthesiology 2002;96:1147-1152. https://doi. org/10.1097/00000542-200205000-00018

9. Cross JP, Mackintosh CG, Griffin JF. Effect of physical restraint and xylazine sedation on haematological values in red deer (Cervus elaphus). Res Vet Sci 1988;45:281-286.

10. Raptopoulos D, Weaver BM, Papanastassopoulou $M$, Staddon GE, Parkinson TJ. The effect of xylazine on plasma thromboxane B2 concentration in sheep. J Vet Pharmacol Ther 1995;18:438-441. https://doi. org/10.1111/j.1365-2885.1995.tb00622.x

\section{Ketamin/ksilazin anestezi hemoreolojik bakış açısından güvenlidir: bir ilk rapor "hakkında-2",}

\section{Erkan Tomatır}

\section{Sayın Editör,}

Akbudak ve ark.'nın “Ketamin/ksilazin anestezi hemoreolojik bakış açısından güvenlidir: bir ilk rapor" başlıklı çalışmanın 11 sıçana ait ilk sonuçlarının bildiri olarak sunulduğu fark edilmiştir. Bildirideki bulgularla karşılaştırıldığında doğrulma, kornea ve çekme refleksleri kaybolma süreleri 18 deneğin sonuçlarına dayalı makalede yaklaşık 2 katına, standart sapmaları da 4 katına çıkmış görünümü vermektedir. Böylesi bir durumda bulguların güvenilirliğinden de kuşku duymak kaçınılmazdır; çünkü denek sayısı artınca standart sapmanın 4 kat artması şöyle dursun, düşmesi beklenir ve bu durum istatistikte yasa gibidir. Saygılarımla. 